International Journal of

Supply Chain and Logistics

(IJSCL)

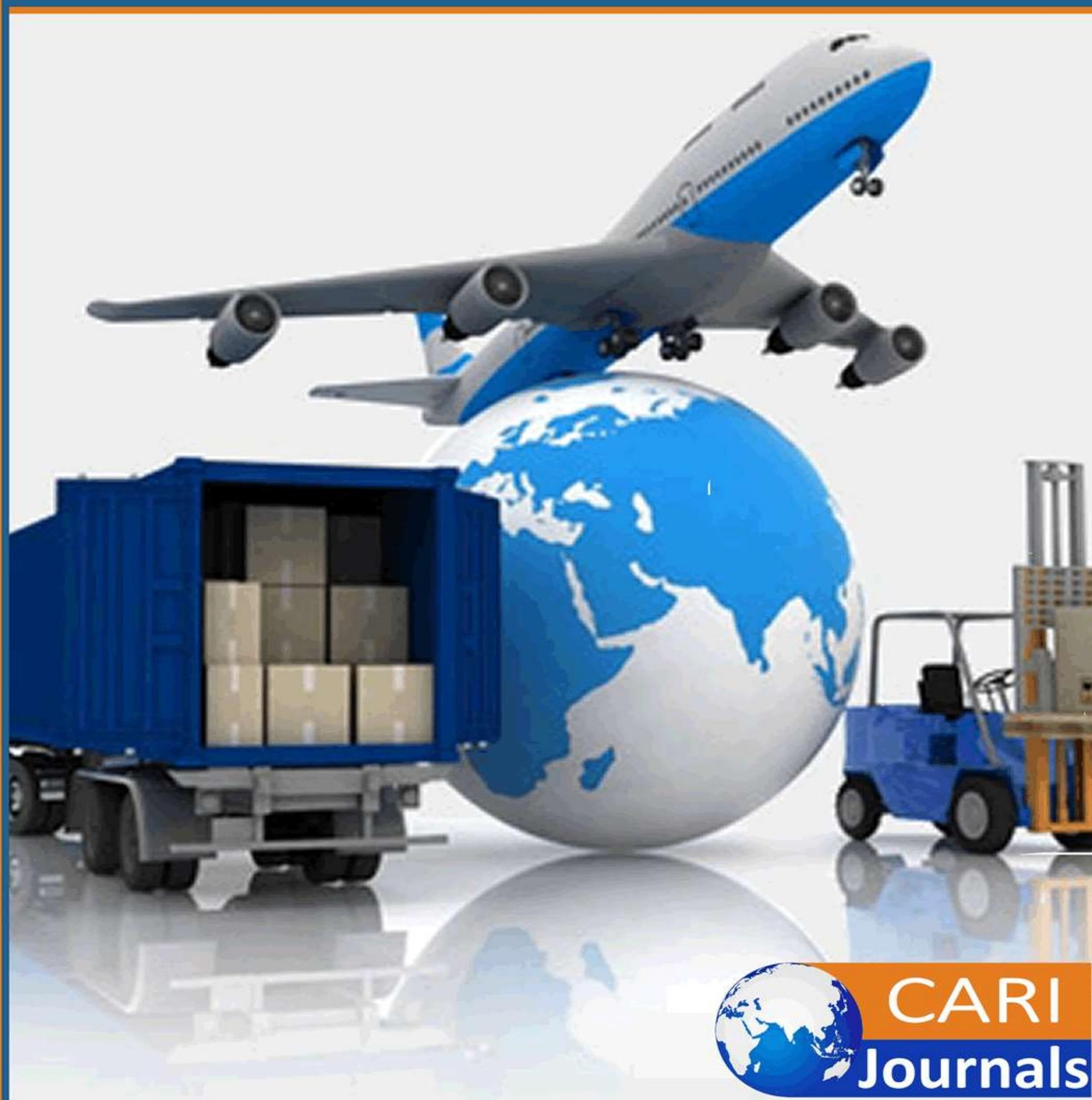




\title{
INFLUENCE OF INFORMATION COMMUNICATION TECHNOLOGY ON PERFORMANCE OF PROCUREMENT AMONG PARASTATALS IN KENYA
}

\author{
1*Jennifer Wawuda, \\ 1*Post Graduate Student, Department of Procurement and Logistics \\ Jomo Kenyatta University of Agriculture and Technology \\ * Author's Email: wawudajay@gmail.com \\ ${ }^{2}$ Dr, Patrick Mwangangi, \\ Lecturer, Department of Procurement and Logistics, \\ Jomo Kenyatta University of Agriculture and Technology
}

\begin{abstract}
Purpose: The purpose of the study was to examine the influence of ICT on performance of procurement with an aim of making recommendations on proper use of ICT.

Methodology: This study adopted a descriptive research design approach targeting heads of procurement and ICT at the 187 parastatals. The study preferred this method because it allowed an in-depth study of the subject. To gather data, structured questionnaire will be used to collect data from a sample of one hundred and thirty (130) respondents, who were selected using simple random sampling, from the four strata. Once collected, data was analyzed using descriptive and inferential statistics. Quantitative data was analyzed using multiple regression analysis. The qualitative data generated was analyzed by use of Statistical Package of Social Sciences (SPSS) version 22 .

Results: The findings of the study indicated that inventory management systems, electronic vendor evaluation, electronic payments and electronic sourcing have a positive relationship with procurement performance among parastatals in Kenya.

Conclusion: Based on the study findings, the study concludes that performance of procurement among parastatals can be improved by inventory management systems, electronic vendor evaluation, electronic payments and electronic sourcing.

Policy recommendation: The study recommended that public institutions should embrace information communication technology so as to improve performance and further researches should to be carried out in other public institutions to find out if the same results can be obtained.
\end{abstract}

Keywords: inventory management systems, electronic vendor evaluation, electronic payments, electronic sourcing 
International Journal of Supply Chain and Logistics

ISSN 2520-3983 (Online)

Vol. 2, Issue 1, pp 40 - 66, 2018

www.carijournals.org

\subsection{INTRODUCTION}

\subsection{Background of the Study}

The study sets out to investigate influence of information communication technology on performance of procurement among parastatals in Kenya. To this end, this chapter builds the case by introducing the problem warranting the study. This chapter presents; the background of the study, problem statement, objectives, research questions, importance of the study, the scope of the study and limitations of the study.

Internet technology has provided organizations with vast opportunities to operate beyond their traditional physical boundaries. More specifically ICT practices have provided manufacturing and service firms with more efficient solutions to drive significant value into their business (Premkumar, 2009). Indeed in 2001 one of the major advocates of internet based business strategies, Michael Porter, professed that if firms were intent on remaining competitive they would have to adapt their business models to accommodate more effective and efficient internet based business approaches.

Such adaptation has however, produced both positive and negative effects for firms in relation to commercial relationships and ICT practices deployment (Porter \& Millar, 2009). The purchasing of goods and services in the public sector is central because it supports all functions of government; each governmental unit needs supplies and equipment to accomplish its mission (Oliveira \& Martins, 2011). Lysons (2013) opined that one of the most important challenges in government procurement is how to best utilize information technology in an age of communications revolution. The issue has been discussed both from a technological perspective and a managerial perspective (Lavelle \& Bardon, 2009)

\subsubsection{Global Perspective on E-Procurement}

According to Eadie, Perera and Heaney (2011) there is a gap between theory and practice. In the field of e-procurement many studies have concentrated in the USA and other large economies such as Germany and Japan. Despite the compelling nature of the case for public sector ICT procurement practices that has been made both by formal, governmental-sponsored reviews, and perhaps more importantly through the positive experiences of private sector organizations, there is very little evidence that it has been widely adopted within the UK public sector. A study by Klein, Conn and Sorra (2010) of government purchasing strategies found that only $13 \%$ of orders are sent electronically; $3 \%$ of invoices are received and processed electronically and $6 \%$ of tenders are transacted electronically.

\subsubsection{Regional Perspective}

According to Aboelmaged (2009) a serious subject of doubt is that the availability of the facilities necessary for participation in ICT practices by industry practitioners is in question. Most professional ICT practices in Nigeria make use of stand-alone computers running few application packages for word processing and spread sheeting. A moderately high level of proficiency in the use of ICT tools is also a pre-requisite for the use of procurement facility by stakeholders. 


\subsubsection{Local Perspective}

Kenya's trade liberalization has accelerated since the early 1990s, thus stimulating imports and improving access to alternative and superior technologies. With the advent of globalization and global financial crisis, adopting information and communication technology in Kenyan parastatals have become increasingly important. For example national gender and equality commission has adopted systems such as RTGS in its procurement processes (Amayi, 2011).

On the other hand, the judicial service commission has an online tendering portal (Maina, 2011). The manual processes are costly, slow, inefficient and data storage and retrieval poor. This project sought to determine e-procurement practices in public sector, find the factors for slow adoption, existing models in use, and then develop a model for the Kenyan public sector.

\subsubsection{ICT Practices in Public Sector in Kenya}

With the coming of information technology, this route has been simplified and speeded up greatly, thanks to synchronized interface with preapproved suppliers and business partners, no matter their location in the world. With online transaction, procurement processes can be approved online and the order fulfilled within minutes; where the required item, often arrives in real time (Songip, Lau, Jusoff \& Ramli, 2013).

Firms in diverse industries, such food and beverage manufacturing firms use electronic procurement in an attempt to increase the efficiency of the purchasing/supply management function and to reduce costs. For example, Kenchic Limited has adopted point of sale systems to track and trace every transaction. Samuelson (2008) defined ICT procurement practices as "business-to-business purchasing practice that utilizes electronic commerce to identify potential sources of supply, to purchase goods and services, to transfer payment, and to interact with suppliers". E-procurement is part of a broader concept called information technology

\subsection{Objectives of the Study}

1. To assess the influence of inventory management systems on performance of procurement among parastatals in Kenya

2. To establish the influence of electronic vendor evaluation on performance of procurement among parastatals in Kenya

3. To determine the influence of electronic payments on performance of procurement among parastatals in Kenya

4. To evaluate the influence of electronic sourcing on performance of procurement among parastatals in Kenya

\subsection{LITERATURE REVIEW}

\subsubsection{Inventory Management Systems}

Inventory management systems in this study will be considered as an ICT practice variable that influences performance of procurement in the parastatals. The attributes of electronic inventory management which will be taken into consideration in this study are: automated reorder systems, EOQ models and bar coding of items. Lean management is getting more and more attention in 
today's highly competitive environment. The proponents of electronic inventory system argue that excess inventory will adversely affect the net cash flows of a firm (Moon, 2015).

On the cost side, most obvious are the costs of holding inventory, which include the capital costs (interest or opportunity) and the physical cost (storage, insurance and spoilage). In recent years, a number of electronic inventory systems have been developed in the field of operations management to deal with excess inventory problem. Management oriented systems include the automated reorder systems, EOQ models and bar coding of items. These organization wide practices encompass the entire supply chain (Wong \& Sloan, 2014).

\subsubsection{Electronic Vendor Evaluation}

Electronic vendor evaluation in this study will be considered as an ICT practice variable that influences performance of procurement in the parastatals. The attributes of electronic vendor evaluation which will be taken into consideration in this study are: financial capacity, supplier quality index and technical capacity. Vendor evaluation is the evaluation and monitoring of supplier capability to ensure successful delivery of commercial outcomes.

It is an essential part of strategic sourcing, vendor management and securing competitive advantage (Rotich, 2011). It is best considered in two phases, pre-contract and post-contract often referred to as contract management. The pre contract involves assessment of potential vendors' capability of controlling quality, delivery, quantity, price and all other factors embodied in a contract while the post-contract involves assessing ongoing vendor performance, deciding what to monitor and the success factors involved (Bradley, 2015).

\subsubsection{Electronic Payments}

Electronic payments in this study will be considered as an ICT practice variable that influences performance of procurement in the parastatals. The attributes of e-payments which will be taken into consideration in this study are: electronic funds transfer, RTGS and e-Cheques and E-cards and m-payments. Electronic payment is the fastest growth area in the global economy and almost carries potentials beyond measure. It provides consumers with the benefits of anytime, anywhere transactions, with lower costs. Moreover it shortens the distance between the buyer and the seller and shrinks the world into a small village (Wong et al., 2014).

The uptake of e-payment is influenced by its potential to create business value and by awareness of its participants of the potential benefits (Sanders, 2015). A major reason for most companies, irrespective of size, to participate in business is to extract some benefit from it. Electronic payment is no different (Rankin et al., 2008). Peleg et al (2012) stated more than ten electronic payment benefits for both buyer and seller. Such as cost savings and speed in selling and purchasing, exposure to new customers (global reach), convenience and transparency to users, better quality of product/service, reduce need for office space and fewer resources required.

\subsubsection{Electronic Sourcing}

Electronic sourcing in this study will be considered as an ICT practice variable that influences performance of procurement in the parastatals. The attributes of e-sourcing which will be taken into consideration in this study are: e-market research, e-catalogues and e-requisitions. Premkumar (2009) in his study argues that e-sourcing is the process of identifying next supplies for a specific spend category, using internet technology usually the internet itself. By identifying 
new suppliers a purchaser can increase the competitiveness in the tactical purchasing process for this spend category hence improve supply chain performance.

Segev (2011) argues that e-sourcing is the process of creating and approving purchasing requisition, placing purchase orders as well as receiving goods and services ordered, by using a software system based on internet technology which greatly improves the supply chain performance. In the case of e- sourcing, the goods and services ordered are indirect goods and services i.e., non-product related goods and services

\subsection{Theoretical review}

\subsubsection{The Technology Acceptance Model (TAM)}

This model was developed and validated by Davis (1993), he used technology acceptance model (TAM) to explain the mechanisms that influence and shape users' acceptance of new information technology such as electronic tendering (Minahan \& Degan, 2011). Inventory management system as an information technology application consists of useful tools for users to save money and increase organizations' effectiveness and efficiency (Davila, Gupta \& Palmer, 2013).

Process cost savings, reduced administration costs, decrease in costs through reduced staffing levels, increased quality through increased competition, placing purchase orders, reduction in time through improved internal workflow and shortened overall procurement cycle times through aspects like automated reorder system, compose some of the benefits that stem of inventory management system (Kheng \& Al-Hawamdeh, 2012).

According to TAM, there are two specific variables that are fundamental determinants of users' attitude toward using information technology and actual use of the system: perceived usefulness and perceived ease of use relatively to new information system design features (Eadie, Perera \& Heaney, 2011). If users realize that bar coding of items is quicker and efficient, then their acceptance will be more likely (Bilali \& Bwisa, 2015).

Many researchers have conducted empirical studies to examine the explanatory power of the TAM, which produced relatively consistent results on the acceptance behavior of IT end users (Aboelmaged, 2009). In summary, TAM provided an explanation of the determinants of technology acceptance that enables explanation of user behavior across a wide scope of end-user information technologies and user populations (McIntosh \& Sloan, 2011). Technology acceptance model is relevant in that it explains parastatals are increasingly accepting and using new technologies in inventory management and ICT procurement activities which consequently is improving procurement performance. 
International Journal of Supply Chain and Logistics

ISSN 2520-3983 (Online)

Vol. 2, Issue 1, pp 40 - 66, 2018

\subsection{CONCEPTUAL FRAMEWORK}

\section{Inventory Management Systems}

- Automated Reorder System

- EOQ Models

- Bar Coding of Items

\section{Electronic Vendor Evaluation}

- Financial Capacity

- Supplier Quality Index

- Technical Capacity

\section{Electronic Payments}

- Electronic Funds Transfer

- RTGS and E-Cheques

- E-Cards and M-Payments

\section{Electronic Sourcing}

- E-Market Research

- E-Catalogues

- E-Requisitions

\section{Independent Variables}

\section{Procurement Performance}

- Timely Delivery

- Customer Satisfaction

- Reduced Procurement Costs

\section{Figure 2.1: Conceptual Framework}

\section{0 METHODOLOGY}

This study adopted a descriptive research design approach targeting heads of procurement and ICT at the 187 parastatals. The study preferred this method because it allowed an in-depth study of the subject. To gather data, structured questionnaire will be used to collect data from a sample of one hundred and thirty (130) respondents, who were selected using simple random sampling, from the four strata. Once collected, data was analyzed using descriptive and inferential statistics. Quantitative data was analyzed using multiple regression analysis. The qualitative data generated was analyzed by use of Statistical Package of Social Sciences (SPSS) version 22. 


\section{0 RESULTS FINDINGS}

\subsection{Descriptive Statistics}

\subsubsection{Inventory Management Systems}

The first objective of the study was to assess the influence of inventory management systems on performance of procurement among parastatals in Kenya. The respondents were asked to indicate to what extent did inventory management systems influence had on performance of procurement among parastatals in Kenya. Results indicated that majority of the respondents $25 \%$ agreed that it was to a very great extent, $27 \%$ said that it was to a great extent, $35 \%$ said it was moderate, while little extent and not all were at 5 and $8 \%$ respectively.

\section{Inventory Management Systems}

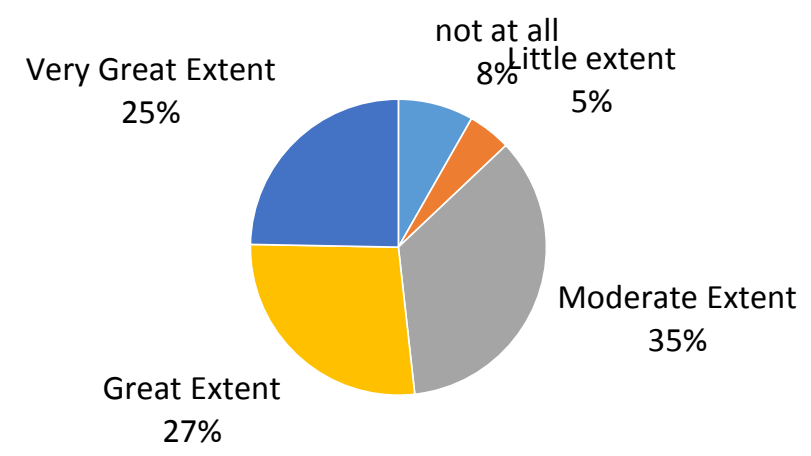

Figure: 1 Inventory Management Systems

The respondents were also asked to comment on statements regarding inventory management systems influence on performance of procurement among parastatals in Kenya. The responses were rated on a likert scale and the results presented in Table 4.6 below. It was rated on a 5 point Likert scale ranging from; $1=$ strongly disagree to $5=$ strongly agree. The scores of 'strongly disagree' and 'disagree' have been taken to represent a statement not agreed upon, equivalent to mean score of 0 to 2.5. The score of 'neutral' has been taken to represent a statement agreed upon, equivalent to a mean score of 2.6 to 3.4. The score of 'agree' and 'strongly agree' have been taken to represent a statement highly agreed upon equivalent to a mean score of 3.5 to 5 .

The respondents were asked to indicate their descriptive responses for inventory management systems. The result revealed that majority of the respondent with a mean of (4.3) agreed with the statement that automated reorder system greatly reduces delivery time. The measure of dispersion around the mean of the statements was 1 indicating the responses were varied. The result revealed that majority of the respondent with a mean of (3.6) agreed with the statement that EOQ Models greatly reduce delivery time. The measure of dispersion around the mean of the statements was 1.4 indicating the responses were varied. The result revealed that majority of the respondent with a mean of (3.8) agreed with the statement that bar coding of items greatly 
reduces delivery time. The measure of dispersion around the mean of the statements was 1.3 indicating the responses were varied.

The result revealed that majority of the respondent with a mean of (3.0) agreed with the statement that automated reorder system greatly influences customer satisfaction. The measure of dispersion around the mean of the statements was 1.4 indicating the responses were varied. The result in table 4.5.1 revealed that majority of the respondent with a mean of (4.2) agreed with the statement that EOQ Models greatly influence customer satisfaction. The measure of dispersion around the mean of the statements was 1 indicating the responses were varied. The result revealed that majority of the respondent with a mean of (3.7) agreed with the statement that bar coding of items greatly influences customer satisfaction. The measure of dispersion around the mean of the statements was 1 indicating the responses were varied.

The result revealed that majority of the respondent with a mean of (3.4) agreed with the statement that automated reorder system greatly reduces procurement costs. The measure of dispersion around the mean of the statements was 1.3 indicating the responses were varied. The result revealed that majority of the respondent with a mean of (3.8) agreed with the statement that EOQ Models greatly reduces procurement costs. The measure of dispersion around the mean of the statements was 1.2 indicating the responses were varied. The result revealed that majority of the respondent with a mean of (3.8) agreed with the statement that bar coding of items greatly reduces procurement costs. The measure of dispersion around the mean of the statements was 1.2 indicating the responses were varied.

However the variations in the responses were varied as shown by an average standard deviation of 1.5 and an average mean of 3.8. This average mean of 3.8 was mainly built up by responses from commercial and higher education respondents. They are keener on inventory management systems than the other two categories. These findings imply that inventory management systems were at the heart of the organizations. The findings agree with Knudsen (2015) that using inventory management systems when sourcing is a smart move and can reduce expenses significantly. 
International Journal of Supply Chain and Logistics

ISSN 2520-3983 (Online)

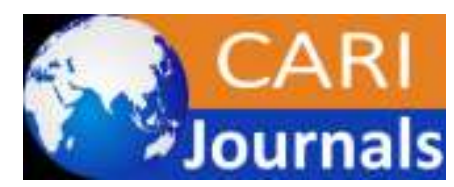

Vol. 2, Issue 1, pp 40 - 66, 2018

$\underline{\text { www.carijournals.org }}$

Table 1: Inventory Management Systems

\begin{tabular}{llll}
\hline Statements & $\mathrm{N}$ & Mean & Std. Deviation \\
\hline Automated reorder system greatly reduces delivery time & 96 & 4.3 & 1.0 \\
EOQ Models greatly reduce delivery time & 96 & 3.6 & 1.4 \\
Bar coding of items greatly reduces delivery time & 96 & 3.8 & 1.3 \\
Automated reorder system greatly influences customer & & & \\
satisfaction & 96 & 3.0 & 1.4 \\
EOQ Models greatly influence customer satisfaction & 96 & 4.2 & 1.0 \\
Bar coding of items greatly influences customer satisfaction & 96 & 3.7 & 0.5 \\
Automated reorder system greatly reduces procurement & & & \\
costs & 96 & 3.4 & 1.3 \\
EOQ Models greatly reduces procurement costs & 96 & 4.1 & 4.3 \\
Bar coding of items greatly reduces procurement costs & 96 & 3.8 & 1.2 \\
Average & 96 & 3.8 & 1.5 \\
\hline
\end{tabular}

\subsubsection{Electronic Vendor Evaluation}

The second objective of the study was to investigate the influence of electronic vendor evaluation on performance of procurement among parastatals in Kenya. The respondents were asked to indicate to what extent did electronic vendor evaluation influenced performance of procurement among parastatals in Kenya. Results indicated that majority of the respondents 31\% agreed that it was to a very great extent, $36 \%$ said that it was to a great extent, $23 \%$ said it was moderate, while little extent and not all tied at $5 \%$.

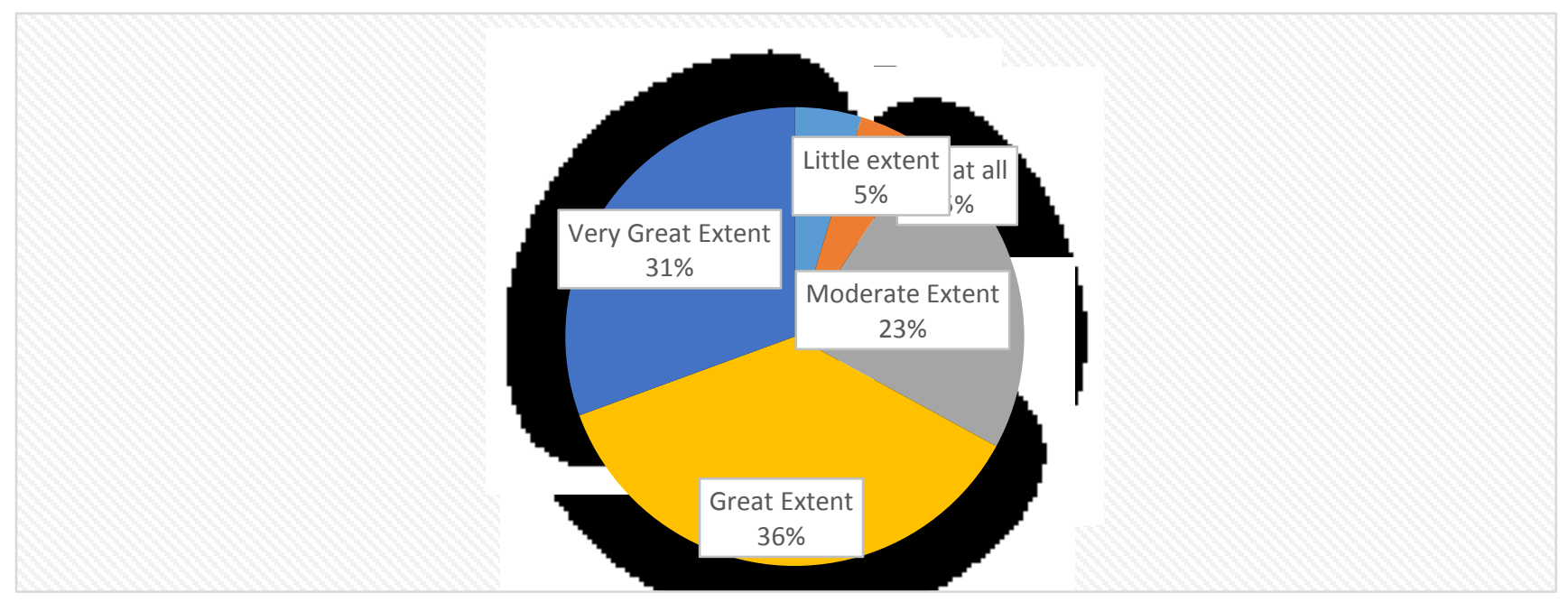

Figure 3: Electronic Vendor Evaluation

The respondents were also asked to comment on statements regarding electronic vendor evaluation influence on performance of procurement among parastatals in Kenya. The respondents were asked to indicate descriptive responses for electronic vendor evaluation. 
The result revealed that majority of the respondents as indicated by a mean of (3.8) indicated that they agreed with the statement that establishing the financial capacity greatly reduces delivery time. The responses were varied as measured by standard deviation of 1.1 . The result revealed that majority of the respondents as indicated by a mean of (3.6) indicated that they agreed with the statement that establishing the supplier quality index greatly reduces delivery time. The responses were varied as measured by standard deviation of 1.1. The result revealed that majority of the respondents as indicated by a mean of (3.7) indicated that they agreed with the statement that establishing the technical capacity reduces delivery time. The responses were varied as measured by standard deviation of 1.1

The result revealed that majority of the respondents as indicated by a mean of (3.6) indicated that they agreed with the statement that establishing the financial capacity greatly influences customer satisfaction. The responses were varied as measured by standard deviation of 1.2. The result revealed that majority of the respondents as indicated by a mean of (3.6) indicated that they agreed with the statement that establishing the supplier quality index greatly influences customer satisfaction. The responses were varied as measured by standard deviation of 1.2. The result revealed that majority of the respondents as indicated by a mean of (3.5) indicated that they agreed with the statement that establishing the technical capacity greatly influences customer satisfaction. The responses were varied as measured by standard deviation of 1.4.

The result revealed that majority of the respondents as indicated by a mean of (3.5) indicated that they agreed with the statement that establishing the financial capacity greatly reduces procurement costs. The responses were varied as measured by standard deviation of 1.4. The result revealed that majority of the respondents as indicated by a mean of (3.3) indicated that they agreed with the statement that establishing the supplier quality index greatly reduces procurement costs. The responses were varied as measured by standard deviation of 1.5 . The result revealed that majority of the respondents as indicated by a mean of (3.6) indicated that they agreed with the statement that establishing the technical capacity greatly reduces procurement costs. The responses were varied as measured by standard deviation of 0.5 .

However the variations in the responses were varied as shown by an average standard deviation of 1.2 and an average mean of 3.6. This average mean of 3.6 was mainly built up by responses from all categories of respondents i.e. commercial, executive, independent regulatory agencies and higher education. This means that electronic vendor evaluation is an important aspect across the parastatals. They are keener on inventory management systems than the other two categories. These findings imply that electronic vendor evaluation were at the heart of the organization. They agree with Lysons (2013) that organizations must look toward their vendor evaluation improvements. The opportunities for cost savings and operational improvements can be enormous as the impact on profitability is considerable. 
International Journal of Supply Chain and Logistics

ISSN 2520-3983 (Online)

Vol. 2, Issue 1, pp 40 - 66, 2018

www.carijournals.org

Table 2: Electronic Vendor Evaluation

\begin{tabular}{|c|c|c|c|}
\hline Statements & $\mathrm{N}$ & Mean & Std. Deviation \\
\hline Establishing the financial capacity greatly reduces delivery time & 96 & 3.8 & 1.1 \\
\hline Establishing the supplier quality index greatly reduces delivery time & 96 & 3.6 & 1.1 \\
\hline Establishing the technical capacity reduces delivery time & 96 & 3.7 & 1.1 \\
\hline $\begin{array}{l}\text { Establishing the financial capacity greatly influences customer } \\
\text { satisfaction }\end{array}$ & 96 & 3.5 & 1.2 \\
\hline $\begin{array}{l}\text { Establishing the supplier quality index greatly influences customer } \\
\text { satisfaction }\end{array}$ & 96 & 3.8 & 1.2 \\
\hline $\begin{array}{l}\text { Establishing the technical capacity greatly influences customer } \\
\text { satisfaction }\end{array}$ & 96 & 3.5 & 1.4 \\
\hline $\begin{array}{l}\text { Establishing the financial capacity greatly reduces procurement } \\
\text { costs }\end{array}$ & 96 & 3.5 & 1.4 \\
\hline $\begin{array}{l}\text { Establishing the supplier quality index greatly reduces procurement } \\
\text { costs }\end{array}$ & 96 & 3.3 & 1.5 \\
\hline $\begin{array}{l}\text { Establishing the technical capacity greatly reduces procurement } \\
\text { costs }\end{array}$ & 96 & 3.6 & 0.5 \\
\hline Average & 96 & 3.6 & 1.2 \\
\hline
\end{tabular}

\subsubsection{Electronic Payments}

There was also need to establish how electronic payments influenced performance of procurement among parastatals in Kenya as the third objective. The respondents were asked to comment on extent of electronic payments influence performance of procurement among parastatals. Results indicated that majority of the respondents $21 \%$ agreed that it was to a very great extent, $22 \%$ said that it was to a great extent, $21 \%$ said it was moderate; little extent was $28 \%$ and not all at $8 \%$.

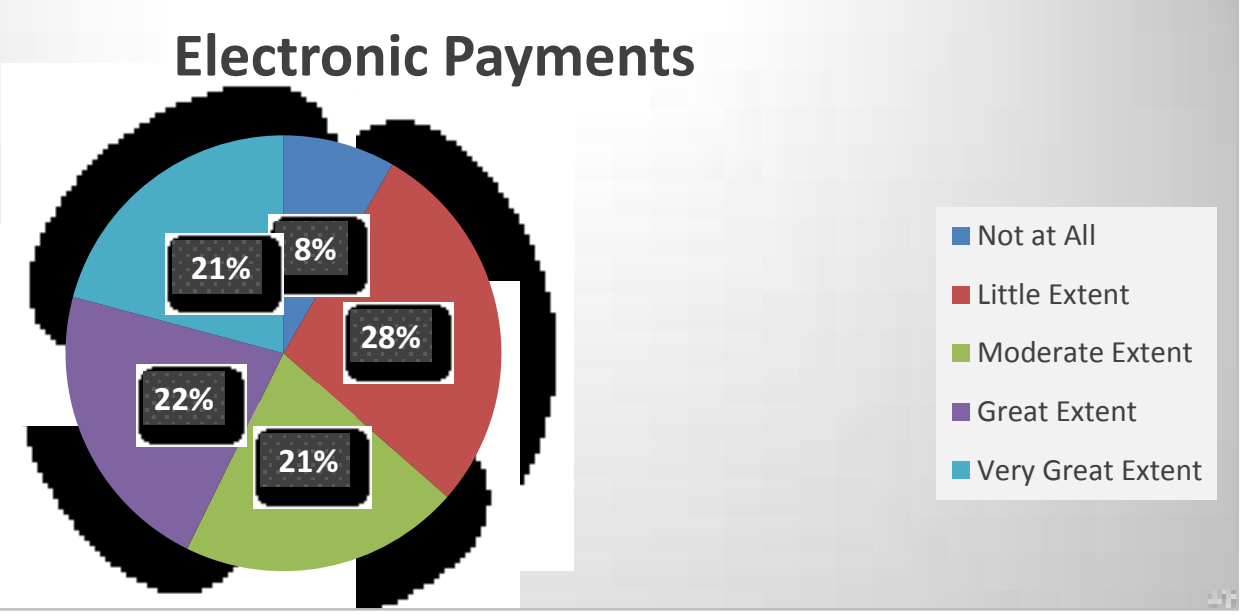

\section{Figure 4: Electronic Payments}

The respondents were asked to indicate their levels of agreement on statements regarding electronic payment. The results revealed that majority of the respondent (3.9) agreed with the 
statement that their electronic funds transfer greatly reduces delivery time. The responses were varied as shown by the standard deviation of 1.2. The results revealed that majority of the respondent (3.2) agreed with the statement that RTGS and e-cheques greatly reduce delivery time. The responses were varied as shown by the standard deviation of 1.3. The results revealed that majority of the respondent (4.0) agreed with the statement that electronic cards and Mpayments reduce delivery time. The responses were varied as shown by the standard deviation of 8 .

The results revealed that majority of the respondent (4.2) agreed with the statement that electronic funds transfer greatly influences customer satisfaction. The responses were varied as shown by the standard deviation of .9. The results revealed that majority of the respondent (3.7) agreed with the statement that RTGS and e-cheques greatly influence customer satisfaction. The responses were varied as shown by the standard deviation of .5. The results revealed that majority of the respondent (2.4) agreed with the statement that electronic cards and M-payments greatly influence customer satisfaction. The responses were varied as shown by the standard deviation of 1.3.

The results revealed that majority of the respondent (3.1) agreed with the statement that Electronic funds transfer greatly reduces procurement costs. The responses were varied as shown by the standard deviation of 1.2. The results revealed that majority of the respondent (3.2) agreed with the statement that RTGS and e-cheques points greatly reduce procurement costs. The responses were varied as shown by the standard deviation of 1.3. The results revealed that majority of the respondent (3.5) agreed with the statement that Electronic cards and M-Payments greatly reduce procurement costs. The responses were varied as shown by the standard deviation of 1.3 .

The average mean of all the statements was 3.7 indicating that majority of the respondents agreed on electronic payments influence on procurement performance of parastatals in Kenya. This average mean of 3.7 was mainly built up by responses from commercial and executive agencies category of respondents. They practice electronic payments often than the other two categories. However the variations in the responses were varied as shown by a standard deviation of 1.1 .

These findings imply that through electronic payments, companies can improve competitive positioning, gain entry to new dynamic and technology driven markets (Maina, 2008). 
International Journal of Supply Chain and Logistics

ISSN 2520-3983 (Online)

Vol. 2, Issue 1, pp $40-66,2018$

$\underline{\text { www.carijournals.org }}$

Table 3: Electronic Payments

\begin{tabular}{|c|c|c|c|}
\hline Statements & $\mathrm{N}$ & Mean & $\begin{array}{l}\text { Std. } \\
\text { Deviation }\end{array}$ \\
\hline Electronic funds transfer greatly reduces delivery time & 96 & 3.9 & 1.2 \\
\hline RTGS and e-Cheques greatly reduces delivery time & 96 & 3.2 & 1.3 \\
\hline Electronic cards and M-Payments reduces delivery time & 96 & 4.0 & 0.8 \\
\hline $\begin{array}{l}\text { Electronic funds transfer greatly influences customer } \\
\text { satisfaction }\end{array}$ & 96 & 4.2 & 0.9 \\
\hline $\begin{array}{l}\text { RTGS and e-Cheques greatly influences customer } \\
\text { satisfaction }\end{array}$ & 96 & 3.7 & 0.5 \\
\hline $\begin{array}{l}\text { Electronic cards and M-Payments greatly influences } \\
\text { customer satisfaction }\end{array}$ & 96 & 2.4 & 1.3 \\
\hline Electronic funds transfer greatly reduces procurement costs & 96 & 3.1 & 1.2 \\
\hline $\begin{array}{l}\text { RIGS and e-Cheques points greatly reduces procurement } \\
\text { costs }\end{array}$ & 96 & 3.2 & 1.3 \\
\hline $\begin{array}{l}\text { Electronic cards and M-Payments greatly reduces } \\
\text { procurement costs }\end{array}$ & 96 & 3.5 & 1.3 \\
\hline Average & 96 & 3.7 & 1.1 \\
\hline
\end{tabular}

\subsubsection{Electronic sourcing}

There was also need to establish how electronic sourcing influences performance of procurement among parastatals. The respondents were also asked to comment on statements regarding electronic sourcing influenced performance of procurement among parastatals. Results also showed that $3 \%$ of respondents indicated to very great extent, great extent was at $12 \%$, moderate extent was $37 \%$, while little extent was at $27 \%$ and not at all was at $21 \%$.

\section{Electronic Sourcing}

Very Great Extent, 3\%

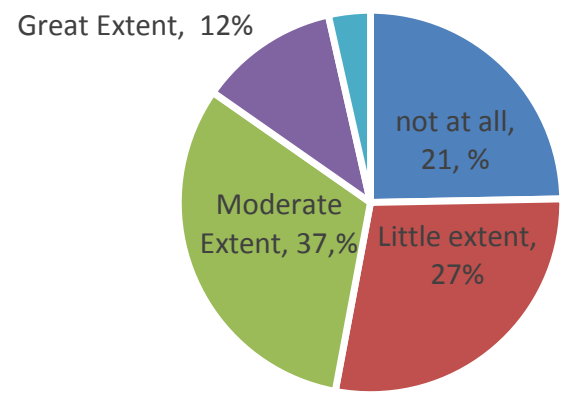

Figure 5: Electronic Sourcing 
The respondents were asked to indicate the descriptive responses for electronic sourcing. The result revealed that majority of the respondent (3.2) agreed with the statement that their electronic market research greatly reduces delivery time. The responses were varied as shown by a standard deviation of 1.3. The result revealed that majority of the respondent (3.2) agreed with the statement that their electronic catalogues greatly reduce delivery time. The responses were varied as shown by a standard deviation of 1 . The result revealed that majority of the respondent (4.3) agreed with the statement that their electronic requisitions reduce delivery time. The responses were varied as shown by a standard deviation of 1 .

The result revealed that majority of the respondent (4.2) agreed with the statement that electronic marketing research greatly influences customer satisfaction. The responses were varied as shown by a standard deviation of 0.8 . The result revealed that majority of the respondent (4.1) agreed with the statement that electronic catalogues greatly influences customer satisfaction. The responses were varied as shown by a standard deviation of 1 . The result revealed that majority of the respondent (4.2) agreed with the statement that electronic requisitions greatly influence customer satisfaction. The responses were varied as shown by a standard deviation of 0.8

The result revealed that majority of the respondent (4.4) agreed with the statement that electronic marketing research greatly reduce procurement costs. The responses were varied as shown by a standard deviation of 0.6. The result revealed that majority of the respondent (4.4) agreed with the statement that electronic catalogues points greatly reduce procurement costs. The responses were varied as shown by a standard deviation of 0.6 . The result revealed that majority of the respondent (4.4) agreed with the statement that electronic requisitions greatly reduce procurement costs. The responses were varied as shown by a standard deviation of 0.7 .

The average mean response for the statements on electronic sourcing was 4.4 indicating there was agreement on electronic sourcing, the variations in the responses was 0.9. This average mean of 4.4 was mainly built up by responses from all the four categories of respondents. This means electronic sourcing is paramount in all the four types of parastatals. The results imply that an organization benefits greatly when electronic sourcing is embraced to reduce costs (Bird, 2009). 
International Journal of Supply Chain and Logistics

ISSN 2520-3983 (Online)

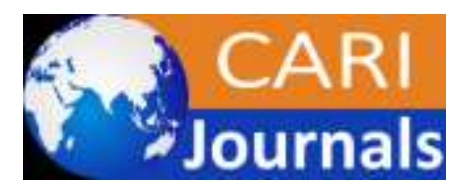

Vol. 2, Issue 1, pp 40 - 66, 2018

$\underline{\text { www.carijournals.org }}$

Table 4: Electronic Sourcing

\begin{tabular}{llll}
\hline Statements & \multicolumn{2}{c}{$\begin{array}{l}\text { Std. } \\
\text { Deviation }\end{array}$} \\
\hline Electronic market research greatly reduces delivery time & $\mathrm{N}$ & Mean & \multicolumn{1}{c}{1.3} \\
Electronic catalogues greatly reduces delivery time & 96 & 3.2 & 1.0 \\
Electronic requisitions reduces delivery time & 96 & 2.9 & 0.9 \\
Electronic marketing research greatly influences customer & 96 & 4.3 & \\
satisfaction & 96 & 4.3 & 0.9 \\
Electronic catalogues greatly influences customer satisfaction & 96 & 4.1 & 1.0 \\
Electronic requisitions greatly influences customer satisfaction & 96 & 4.2 & 0.8 \\
Electronic marketing research greatly reduces procurement costs & 96 & 4.4 & 0.6 \\
Electronic catalogues points greatly reduces procurement costs & 96 & 4.4 & 0.7 \\
Electronic requisitions greatly reduces procurement costs & 96 & 4.4 & 0.6 \\
Average & 96 & 4.4 & 0.9 \\
\hline
\end{tabular}

\subsection{Correlation Analysis}

Correlation analysis was used to determine both the significance and degree of association of the variables and also predict the level of variation in the dependent variable caused by the independent variables in table 5: 
International Journal of Supply Chain and Logistics

ISSN 2520-3983 (Online)

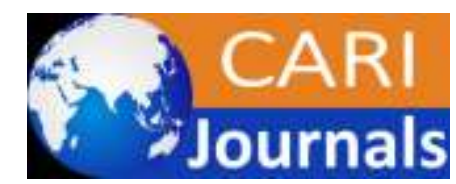

Vol. 2, Issue 1, pp 40 - 66, 2018

$\underline{\text { www.carijournals.org }}$

Table 5: Summary of Pearson's Correlations

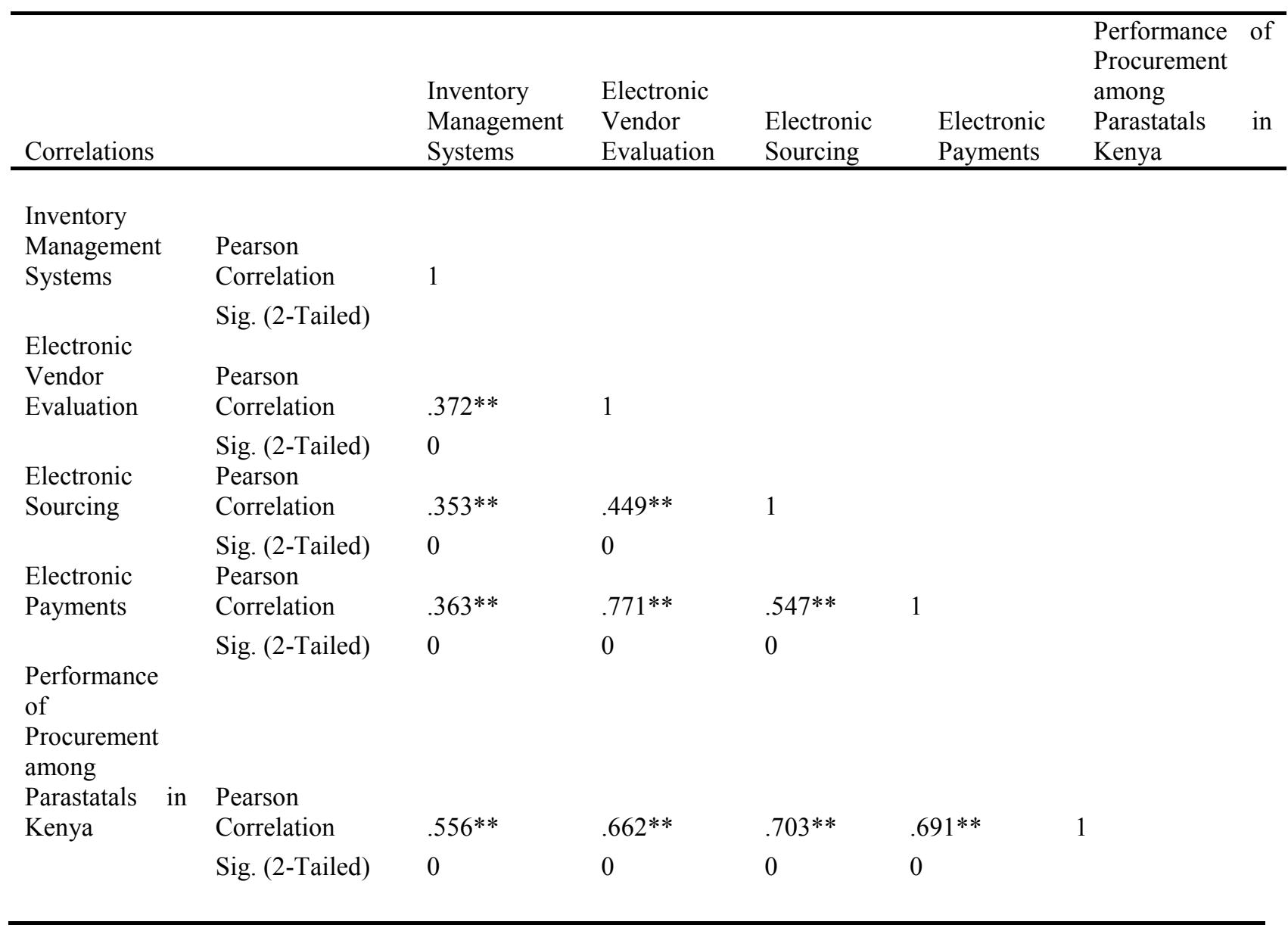

\section{** Correlation is Significant at the 0.05 Level (2-Tailed).}

The correlation summary shown in Table 4.10 indicated that the associations between each of the independent variables and the dependent variable were all significant at the $95 \%$ confidence level. The correlation analysis to determine the relationship between inventory management systems and performance of procurement among parastatals in Kenya, Pearson correlation coefficient computed and tested at 5\% significance level. The results indicate that there was a positive relationship $(\mathrm{r}=0.556)$ between inventory management systems and performance of procurement among parastatals in Kenya. In addition, the researcher found the relationship to be statistically significant at $5 \%$ level $(\mathrm{p}=0.000,<0.05)$.

The correlation analysis to determine the relationship between electronic vendor and performance of procurement among parastatals in Kenya, Pearson correlation coefficient computed and tested at 5\% significance level. The results indicated that there was a positive relationship $(\mathrm{r}=0.662)$ between electronic vendor evaluation and performance of procurement among parastatals in Kenya. In addition, the researcher found the relationship to be statistically significant at $5 \%$ level $(\mathrm{p}=0.000,<0.05)$. 
The correlation analysis to determine the relationship between electronic payment and performance of procurement among parastatals in Kenya, Pearson correlation coefficient computed and tested at 5\% significance level. The results indicate that there was a positive relationship $(\mathrm{r}=0.703)$ between electronic payments and performance of procurement among parastatals in Kenya. In addition, the researcher found the relationship to be statistically significant at $5 \%$ level $(\mathrm{p}=0.000,<0.05)$.

The correlation analysis to determine the relationship between electronic sourcing and performance of procurement among parastatals in Kenya, Pearson correlation coefficient computed and tested at 5\% significance level. The results indicate that there was a positive relationship $(\mathrm{r}=.691)$ between electronic sourcing and performance of procurement among parastatals in Kenya. In addition, the researcher found the relationship to be statistically significant at $5 \%$ level $(p=0.000,<0.05)$. Hence, it was evident that all the independent variables could explain the changes in the performance of procurement among parastatals in Kenya, on the basis of the correlation analysis.

\subsection{Regression Analysis}

In this study multivariate regression analysis was used to determine the significance of the relationship between the dependent variable and all the independent variables pooled together. Regression analysis was conducted to find the proportion in the dependent variable (performance of procurement among parastatals in Kenya.) which can be predicted from the independent variables (inventory management systems, electronic vendor evaluation, electronic payments, electronic sourcing).

Table 6 presented the regression coefficient of independent variables against dependent variable. The results of regression analysis revealed there was a significant positive relationship between dependent variable and the independent variable. The independent variables reported $\mathrm{R}$ value of 0.846 indicating that there was perfect relationship between dependent variable and independent variables. $\mathrm{R}$ square value of 0.715 means that $71.5 \%$ of the corresponding variation in performance of procurement among parastatals in Kenya can be explained or predicted by (inventory management systems, electronic vendor evaluation, electronic payments, electronic sourcing) which indicated that the model fitted the study data. The results of regression analysis revealed that there was a significant positive relationship between dependent variable and independent variable at $(\beta=0.715), \mathrm{p}=0.000<0.05)$. 
International Journal of Supply Chain and Logistics

ISSN 2520-3983 (Online)

Vol. 2, Issue 1, pp 40 - 66, 2018

www.carijournals.org

Table 6: Model Summary

\begin{tabular}{|c|c|c|c|c|}
\hline Model & $\mathbf{R}$ & R Square & Adjusted R Square & $\begin{array}{l}\text { Std. Error of the } \\
\text { Estimate }\end{array}$ \\
\hline 1 & $.846^{\mathrm{a}}$ & .715 & .703 & .14869 \\
\hline
\end{tabular}

a) Predictors: (Constant), Inventory Management Systems, Electronic Vendor Evaluation, Electronic Payments, Electronic Sourcing

b) Dependent Variable: Performance of Procurement among Parastatals

Table 7: ANOVA

\begin{tabular}{lllcllll}
\hline \multirow{2}{*}{ Model } & & $\begin{array}{l}\text { Sum } \\
\text { Squares }\end{array}$ & of df & Mean Square & F & Sig. \\
& & & & & & \\
\hline 1 & Regression & 5.002 & 4 & 1.251 & 56.562 & $\mathbf{. 0 0 0}^{\text {b }}$ \\
& Residual & 1.99 & 91 & 0.022 & & \\
& Total & 6.992 & 95 & & & \\
\hline
\end{tabular}

Predictors: (Constant), Inventory Management Systems, Electronic Vendor Evaluation, Electronic Payments, Electronic Sourcing

Dependent Variable: Performance of Procurement among Parastatals

The significance value is 0.000 which is less than 0.05 thus the model is statistically significance in predicting how inventory management systems, electronic vendor evaluation, electronic payments and electronic sourcing influence performance of procurement among parastatals in Kenya. The F critical at 5\% level of significance was 28.61. Since F calculated which can be noted from the ANOVA table above is 56.562 which is greater than the F critical (value $=28.61$ ), this shows that the overall model was significant. The study therefore establishes that; inventory management systems, electronic vendor evaluation, electronic payments and electronic sourcing were all important information communication technology practices influencing procurement performance of parastatals. These results agree with Odhiambo and Kamau (2013) results which indicated a positive and significant influence of information communication technology on procurement performance of parastatals. 
International Journal of Supply Chain and Logistics

ISSN 2520-3983 (Online)

Vol. 2, Issue 1, pp 40 - 66, 2018

www.carijournals.org

Table 8: Coefficients of Determination

\begin{tabular}{|c|c|c|c|c|c|c|}
\hline \multirow{2}{*}{\multicolumn{2}{|c|}{ Model }} & \multicolumn{2}{|c|}{$\begin{array}{l}\text { Unstandardized } \\
\text { Coefficients }\end{array}$} & \multirow{2}{*}{$\begin{array}{l}\text { Standardized } \\
\text { Coefficients } \\
\text { Beta }\end{array}$} & \multirow[t]{2}{*}{$\mathrm{t}$} & \multirow[t]{2}{*}{ Sig. } \\
\hline & & $\mathrm{B}$ & Std. Error & & & \\
\hline \multirow[t]{6}{*}{1} & (Constant) & 2.07 & 0.193 & & 10.725 & 0.000 \\
\hline & Inventory & 0.166 & 0.041 & 0.255 & 4.048 & 0.000 \\
\hline & Management Systems & & & & & \\
\hline & $\begin{array}{l}\text { Electronic } \quad \text { Vendor } \\
\text { Evaluation }\end{array}$ & 0.138 & 0.053 & 0.235 & 2.603 & 0.01 \\
\hline & Electronic Sourcing & 0.119 & 0.021 & 0.398 & 5.667 & 0.000 \\
\hline & Electronic Payments & 0.09 & 0.043 & 0.201 & 2.093 & 0.037 \\
\hline
\end{tabular}

a) Predictors: (Constant), Inventory Management Systems, Electronic Vendor Evaluation, Electronic Payments, Electronic Sourcing

b) Dependent Variable: Performance of Procurement among Parastatals

The research used a multiple regression model

$\mathrm{Y}=\beta_{0}+\beta_{1} \mathrm{X}_{1}+\beta_{2} \mathrm{X}_{2}+\beta_{3} \mathrm{X}_{3}+\beta_{4} \mathrm{X}_{4}+\mathcal{E}$

The regression equation will be;

$\mathrm{Y}=2.07+0.166 \mathrm{X}_{1}+0.138 \mathrm{X}_{2}+0.119 \mathrm{X}_{3}+0.09 \mathrm{X}_{4}$

The regression equation above has established that taking all factors into account (electronic payments, inventory management systems, electronic sourcing, and electronic vendor evaluation) constant at zero, performance of procurement among parastatals in Kenya will be an index of 2.07. The findings presented also shows that taking all other independent variables at zero, a unit increase in inventory management will lead to a 0.166 increase in procurement performance of parastatals .The P-value was 0.000 which is less 0.05 and thus the relationship was significant.

The study also found that a unit increase in electronic vendor will lead to a 0.138 increase in performance of procurement among parastatals in Kenya. The P-value was 0.00 and thus the relationship was significant. In addition, the study found that a unit increase in electronic Sourcing will lead to a 0.119 increase in the performance of procurement among parastatals in Kenya. The P-value was 0.000 and thus the relationship was significant. Lastly, the study found that a unit increase in electronic payments will lead to a 0.09 increase in the performance of procurement among parastatals in Kenya. The P-value was 0.00 and hence the relationship was significant since the p-value was lower than 0.05 . The findings of the study show that, inventory management systems contributed most to the procurement performance among parastatals in Kenya. 
International Journal of Supply Chain and Logistics

ISSN 2520-3983 (Online)

Vol. 2, Issue 1, pp $40-66,2018$

www.carijournals.org

\section{O SUMMARY, CONCLUSION AND RECOMMENDATIONS}

\subsection{Summary of Findings}

\subsubsection{Inventory Management Systems}

The study sought to assess influence of inventory management systems on performance of procurement among parastatals in Kenya as the first objective of the study. A majority of respondents were found to highly agree that parastatals had embraced inventory management systems with regard to its procurement activities. EOQ models and bar coding of items were common in the parastatals. Correlation and regression results revealed that this was an important variable that could perhaps be explained by the observation from the findings that inventory management systems was an important factor in influencing procurement performance of parastatals.

\subsubsection{Electronic Vendor Evaluation}

The influence of electronic vendor evaluation on performance of procurement among parastatals in Kenya was the second objective of the study. A majority of respondents were found to highly agree that the parastatals had embraced electronic vendor evaluation with regard to its procurement activities. Supplier quality indexing and financial capacity were common in the parastatals. Correlation and regression results revealed that this was an important variable that could perhaps be explained by the observation from the findings that electronic vendor evaluation was an important factor in influencing procurement performance of parastatals.

\subsubsection{Electronic Payments}

The study endeared to assess influence of electronic payments on performance of procurement among parastatals in Kenya as the third objective of the study. A majority of respondents were found to highly agree that the parastatals had embraced electronic payments with regard to its procurement activities. Electronic funds transfer and RTGS were common in the parastatals. Correlation and regression results revealed that this was an important variable that could perhaps be explained by the observation from the findings that electronic payments was an important factor in influencing procurement performance of parastatals.

\subsubsection{Electronic Sourcing}

The study sought to assess influence of electronic sourcing on performance of procurement among parastatals in Kenya as the last objective of the study. A majority of respondents were found to highly agree that the parastatals had embraced electronic sourcing with regard to its procurement activities. E-requisitions and E-catalogues were common in the parastatals. Correlation and regression results revealed that this was an important variable that could perhaps be explained by the observation from the findings that electronic sourcing was an important factor in influencing performance of parastatals.

\subsubsection{Procurement Performance}

The study endeared to determine influence of information communication technology on performance of procurement among parastatals in Kenya. The regression results revealed that information communication technology platforms identified in the study, that is, inventory 
management systems, electronic vendor evaluation, electronic payments and electronic sourcing combined could explain approximately $71.5 \%$ of the variations in the performance of procurement among parastatals. The other $28.5 \%$ may be attributed to other strategies not explained by the model or the variables.

Quality of goods purchased recorded positive growth, timely purchases and stock out reduction further recorded positive growth, cost reductions due to minimal or no reworks also recorded positive growth. From inferential statistics, a positive correlation is seen between each predictor variable and performance of procurement among parastatals. The strongest correlation was established between inventory management systems and performance of procurement among parastatals. All the independent variables were found to have a statistically significant association with the dependent variable at ninety five percent level of confidence.

\subsection{Conclusion of the study}

Based on the study findings, the study concludes that performance of procurement among parastatals can be improved by inventory management systems, electronic vendor evaluation, electronic payments and electronic sourcing.

First, in regard to inventory management systems, the regression coefficients of the study show that it has a significant influence of 0.166 on performance of procurement among parastatals. This implies that increasing levels of inventory management systems by a unit would increase the levels of performance of procurement among parastatals by 0.166 . This shows that inventory management systems has a positive influence on performance of procurement among parastatals.

Second in regard to electronic vendor evaluation, the regression coefficients of the study show that it has a significant influence of 0.138 on performance of procurement among parastatals. This implies that increasing levels of electronic vendor evaluation by a unit would increase the levels of performance of procurement among parastatals by 0.138 . This shows that electronic vendor evaluation has a positive influence on performance of procurement among parastatals.

With regard to electronic sourcing, the regression coefficients of the study show that it has a significant influence of 0.119 on performance of procurement among parastatals. This implies that increasing levels of electronic sourcing by a unit would increase the levels of performance of procurement among parastatals by 0.119 . This shows that electronic sourcing has a positive influence on performance of procurement among parastatals.

Lastly, in regard to the fourth objective, the regression coefficients of the study show that it has a significant influence of 0.09 on performance of procurement among parastatals. This implies that increasing levels of electronic payments by a unit would increase the levels of performance of procurement among parastatals by 0.09 . This shows that electronic payments have a positive influence on performance of procurement among parastatals.

Drawing on this research, lack of inventory management systems, electronic vendor evaluation, electronic payments and electronic sourcing in parastatals is leading to poor procurement performance. Though the parastatals are striving hard to improve their procurement performance there are still issues of poor quality products, long lead time and high cost of projects/products. It was articulated that the current phenomenon of poor procurement performance in the public 
sector can be reversed if the government and other stakeholders ensure inventory management systems, electronic vendor evaluation, electronic payments and electronic sourcing are embraced in the procurement function. Thus, it is evident that all the independent variables identified in this study were all important information communication technology platforms that influenced the performance of procurement among parastatals.

\subsection{Recommendations of the study}

Finally, the study recommended that public institutions should embrace information communication technology so as to improve performance

\subsection{Areas for further studies}

The study is a milestone for further research in the field of performance of procurement among parastatals in Africa and particularly in Kenya. The findings demonstrated the important information communication technology platforms to the performance of parastatals to include; inventory management systems, electronic vendor evaluation, electronic payments and electronic sourcing. The current study obtained an $\mathrm{R}^{2}$ of $71.5 \%$ and should therefore be expanded further in future in order to include other information communication technology platforms that may as well have a positive significance to procurement performance of parastatals. Existing literature indicates that as a future avenue of research, there is need to undertake similar research in other institutions and public sector organizations in Kenya and other countries in order to establish whether the explored information communication technology platforms herein can be generalized to affect procurement performance in other public institutions

\section{REFERENCES}

Aboelmaged, M. G. (2009). Predicting e-procurement Adoption in a Developing Country, Industrial Management and Data Systems, 110(3), 392-414.

Amayi, F. K. (2011). Factors Affecting Procurement in the Public Service: a Case Study of the State Law Office. Eldoret: Moi University.

Bilali, J \& Bwisa, H. (2015). Factors influencing the Adoption of e-Procurement: A case of Garissa County Government. The Strategic Journal of Business \& Change Management, $3(5), 662-682$.

Bird, D.K. (2009). The use of Questionnaires for Acquiring information on Public Perception of Natural hazards and risk mitigation - a review of current knowledge and practice. Nat. Hazards Earth Syst. Sci., 4(9), 1307-1325.

Boer, L., \& Heijboer, G. (2012). A Conceptual Model for Assessing the Impact of Electronic Procurement, European Journal of Purchasing and Supply Management, 8(2), 25-33. 
International Journal of Supply Chain and Logistics

ISSN 2520-3983 (Online)

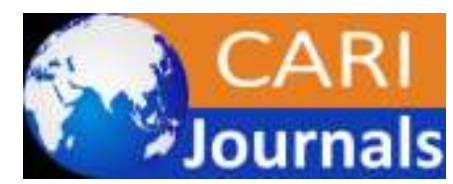

Vol. 2, Issue 1, pp 40 - 66, 2018

$\underline{\text { www.carijournals.org }}$

Bradley, A. (2015). E-procurement: A Long Way to Go. Supply Management, Retrieved from http://www.supplymanagement.com/analysis/features/2005/eprocurement-a-long-way-togo/ on 18 November, 2017.

CCG (2007). National Development Fund Report Instructional Structures and Reforms. Nairobi: Centre for Corporate Governance.

Chan, J. \& Lee, M. (2009). SME e-procurement Adoption in Hong Kong - The Roles of Power, Trust and Value. Proceedings of the 36th Annual Hawaii International Conference on System Sciences, USA 2(9), 10-23.

Croom, S. \& Brandon-Jones, A. (2014). E-Procurement: Key issues in e-Procurement implementation and operation in the public sector, 13th International Purchasing \& Supply Education \& Research Association (IPSERA) Conference, Catania, Italy.

Croom, S. R. (2010). The Impact of Web-based Procurement on the Management of Operating Resources Supply, The Journal of Supply Chain Management, 36(1), 4-13.

Davila, A., Gupta, M. \& Palmer, R. (2013). Moving Procurement Systems to the Internet: the Adoption and Use of e-procurement Technology Models, European Management Journal, 21(1), 11-23.

Eadie, R., Perera, S. \& Heaney, G. (2011). Analysis of the use of E-Procurement in the Public and Private Sectors of the UK construction Industry. Journal of Information Technology in Construction, 2(6), 669-686.

Government of Kenya (2008). Status of the economy, Government press, Nairobi.

Isaac, S., \& Michael, W.B. (2008). Handbook in Research and Evaluation for Education and the Behavioral Sciences, Ohio, U.S.A.

Issa, R., Flood, I. \& Caglasin, G. (2013). Survey of E-Business Implementation in the US Construction Industry. Journal of Information Technology in Construction, 2(8), 15-28.

Kasomo, D. (2007). Research Methods in Humanities and Education, Eldoret; Zapf Chancery.

Kheng, C. \& Al-Hawamdeh, S. (2012). The Adoption of Electronic Procurement in Singapore, Electronic Commerce Research, 2(1), 61-80.

KIPPRA (2010). The Demographic Governance Support Programme (DGSP). Nairobi: KIPPRA.

Klein, K. J., Conn, A. B., \& Sorra, J. S. (2010). Implementing Computerized Technology: An Organizational Analysis. Journal of Applied Psychology, 86(5), 811-824.

Knudsen, D. (2008). Aligning Corporate Strategy, Procurement Strategy and e-procurement Tools. International Journal of Physical Distribution and Logistics Management, 33(8), 720-734. 
International Journal of Supply Chain and Logistics

ISSN 2520-3983 (Online)

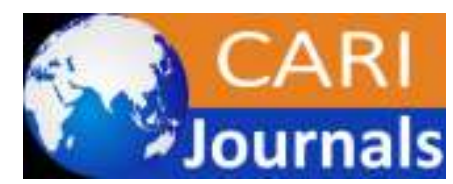

Vol. 2, Issue 1, pp 40 - 66, 2018

$\underline{\text { www.carijournals.org }}$

Lavelle, D \& Bardon, A. (2009). E-tendering in Construction: Time for a Change? Built Environment Research Paper, 2(2), 104-112.

Li, Y. H. (2008). An Empirical Investigation on the Determinants of e-procurement Adoption in Chinese Manufacturing Enterprises. In International Conference on Management Application of e-Procurement Technologies for Selecting Suppliers of Agro-Based SMEs in Malaysia Science and Engineering.

Lysons, K. (2013). Purchasing and supply chain management 7th Edition. New York: McGrawHall.

Maina, E. T. (2011). Factors Influencing the Implementation of the Public Procurement and Disposal Act, 2005 in Kenya: a Case on the Ministry of Education. Nairobi: JKUAT.

Martin, J. (2008). E-tendering about time too. RICS paper. Retrieved from http:// www.rics.org/NR/rdonlyres/EtenderingabouttimetooJoeMartin.pdf on 18 June 2017.

McIntosh, G. \& Sloan, B. (2011). The potential impact of electronic procurement and global sourcing within the UK construction industry. In: ARCOM 17th Annual Conference 2011, (ed), Salford, UK, September 2011, 8(2), 231-239.

Mentzer, J. (2010). Supply Chain management (5th edition). New Dehli: Prentice Hall India.

Minahan, T. \& Degan, G. (2011). Best practices in e-procurement, Boston: Aberdeen Group, TheAbridgedReport.Retrievedfromhttp://www.hedgehog.com/resources/eProcurementAbri dged.pdf on 17 May 2017.

Moon, M. J. (2015). E-procurement Management in State Governments: Diffusion of eprocurement Practices and Its Determinants, Journal of Public Procurement, 5(1), 54-72.

Mugenda \& Mugenda (2008). Research Methods: 1st Edition, Published by ACTS, Nairobi, Kenya.

Ngechu, M. (2009). Understanding the Research Process and Methods. An Introduction to Research Methods. Acts press, Nairobi.

Odhiambo, W. \& Kamau, P. (2013). Public Procurement Lessons from Kenya, Tanzania and Uganda. Research programme on the Integration of Developing Countries into the World Trading System.

Oliveira, T., \& Martins, M.F. (2011). Literature Review of Information Technology Adoption Models at Firm Level. The Electronic Journal Information Systems Evaluation, 14(1), 2334.

Peleg, B., \& Hausman, W. (2012). Short-term e-procurement Strategies vs. Longterm Contracts, Management Review, 5(1), 26-32. 
International Journal of Supply Chain and Logistics

ISSN 2520-3983 (Online)

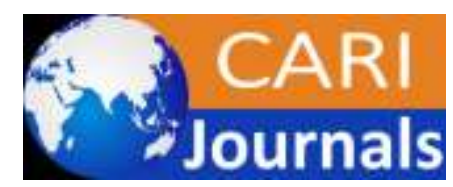

Vol. 2, Issue 1, pp 40 - 66, 2018

$\underline{\text { www.carijournals.org }}$

Petroni, A. \& Braglia, M. (2010). A Quality-assurance Oriented Methodology for Handling Tradeoffs in Supplier Selection, International Journal of Physical Distribution and Logistics Management, 3(2), 96-111.

Porter, E., \& Millar, V.E. (2009). “How information gives you competitive advantage," Harvard: Harvard University.

PPOA (2007). Assessing Procurement Systems in Kenya Report. Nairobi: Public Oversight Authority.

Premkumar, M. R. (2009). Adoption of New Information Technologies in Rural Small Businesses, Omega, 27(4), 467-484.

Public Procurement Oversight Authority (2009). Trends in Electronic Procurement. Kenya Procurement Journal.

Puschmann, T. (2015). Successful Use of e-procurement in Supply Chains, Supply Chain Management: An International Journal, 10(2), 122-133.

Rankin J., Chen Y. \& Christian A. (2008). E-procurement in the Atlantic Canadian AEC industry. $1(1), 75-87$.

Rotich, L. M. (2011). Influence of Planning on Procurement Performance in the Kenya, International Journal of Human Resource and Research Publication, 12(4), 289-292.

Saleemi, N. A. (2010). Purchasing and supplies Management Simplified. Nairobi: Saleemi Publications Limited.

Salford, U. \& Roche, J. (2010). Are you ready for e-procurement? Strategic Finance, 83(1), 56-59.

Samuelson, O. (2008). The I.T-Barometer - A Decade's Development of its Use in The Swedish Construction Sector. Journal of Information Technology in Construction, 1(3), 1-19.

Sanders, N. (2015). IT Alignment in Supply Chain Relationships: A Study of supplier Benefits, Journal of Supply Chain Management, 4(2), 4-13.

Segev, A. \& Gebauer, J. (2011). B2B Procurement and Marketplace Transformation, Information Technology and Management, 8(2), 241-260.

Songip, R., Lau, H., Jusoff, K. \& Ramli, N. (2013). A Working Integrated Model for the Diffusion of Construction Innovation. American Journal of Applied Sciences, 10(2), 147-158.

Teo, H., Lin, S. \& Lai, K. (2009). Adopters and non-adopters of e-Procurement in Singapore: An empirical study, Omega, 37(5), 972-987. 
Thai, K.V. (2007). "Advancing public procurement: practices, innovation and knowledge sharing", Innovation and Knowledge-sharing, Academics Press, Boca Raton, FL.

Thomson, D. \& Jackson, S. (2007). Creativity and Management in Public Sector. In Singapore. a. Mullins, Fundamentals of Management New York: McGraw-Hall.

Trochin, W.M.K. (2009). Research methods. Knowledge base. Kogan Page Ltd, London, UK.

Van Weele, A. J. (2010). Purchasing and Supply Chain Management: Analysis, Strategy, Planning and Practice (4th ed.). Thomson Learning: United Kingdom.

Wang, C., Chang, C. \& Heng, M. (2014). The Levels of Information Technology Adoption, Business Network, and Strategic Position Model for Evaluating Supply Chain Integration, Journal of Electronic Commerce Research, 5(2), 85-98.

Weber, C. A., \& Benton, W. C. (2011). Vendor Selection Criteria and Methods, European Journal Operational Research, 5(1), 2-18.

Wong, C. \& Sloan, B. (2014). Use of ICT for e-procurement in the UK Construction Industry: A Survey of SMEs Readiness. In ARCOM Twentieth Annual Conference 2004, (3ed), Reading, UK, 1-3 September 2014.

World Bank (2013). "Reducing Supply Chain Barriers Could Increase Global GDP Up To 6 Times More Than Removing All Import Tariffs Report", Switzerland. 